\title{
EFFECT OF POPULATION DENSITY AND AVAILABLE DIET ON THE RATE OF BROOD REARING BY HONEY BEES OFFERED A POLLEN SUBSTITUTE
}

\author{
E. W. HERBERT, Jr., and H. SHIMANUKI \\ U.S. Department of Agriculture, ARS, PPI \\ Bioenvironmental Bee Laboratory, Beltsville, MD 20705, USA
}

\begin{abstract}
SUMMARY
The amount of brood rearing and diet consumption by colonies of honey bees established with either 200,400 , or $600 \mathrm{~g}$ of newly-emerged bees was measured when each population was offered either 25,50 , or $100 \mathrm{~g}$ of a lactalbumin-yeast pollen substitute per week. The linear equation and $r^{2}$ value (coefficient of determination) for each treatment showed that the amount of available diet influenced the rate of brood rearing more than the populations, especially when $100 \mathrm{~g}$ of diet were made available weekly. Yields of brood increased with available diet in all three population levels. Bees reared the most brood to the sealed stage in units populated with $400 \mathrm{~g}$ of bees and offered $100 \mathrm{~g}$ of diet.
\end{abstract}

The amount of nectar and pollen a colony collects, the amount of brood produced in addition to numerous environmental conditions are all factors responsible for the survival of a colony. These factors are interrelated and because of the difficulty of controlling each independently of the others in free flying colonies, many predications about colony development are, in fact, only estimates. Many researchers have proposed population models in an attempt to determine the intereaction of various life processes in honey bee colonies.

From previous studies using small nuclei of bees confined in flight cages, we observed that bees often consumed large amounts of pollen and pollen supplements without an apparent increase in the rate of brood rearing. Doull (1973) noted that the consumption of pollen supplements varied in direct relationship to the amount of brood in the colony. FreE (1968) observed that colonies appeared to have similar amounts of brood irrespective of the size, so the ratio of brood/bee was greater in smaller colonies. More food was consumed per bee in small than in large colonies. 
Our standard bioassay at Beltsville, to evaluate pollen substitutes, involves the use of caged colonies of bees. The optimum colony population and amount of available diet for each colony for maximum brood production has yet to be determined. In a caged environment, the amount of food intake can be carefully regulated and colonies can be established using exact numbers of bees instead of weighing free flying colonies and estimating colony size.

The purpose of this experiment was to determine the relationship between the amount of brood reared, colony population, and the consumption of a lactalbuminyeast pollen substitute in caged honey bee colonies.

\section{MATERIALS AND METHODS}

Test colonies were established in small hives $(23 \times 19 \times 27 \mathrm{~cm})$ normally used for queen mating. Each hive contained five drawn shallow combs $(3 \times 16 \times 24 \mathrm{~cm})$ free of any pollen or honey and a mated laying queen. Individual colonies were placed in a screen flight cage $(2 \times 2 \times 2 \mathrm{~m})$.

Individual test colonies were established with either 200,400 , or $600 \mathrm{~g}$ of newly-emerged bees and offered 25,50 , or $100 \mathrm{~g}$ of diet per week. Each population and diet combination was replicated 4 times.

Eight additional units were established as controls. These units were each established with $400 \mathrm{~g}$ of newly emerged bees and 4 were offered $50 \mathrm{~g}$ of year-old pollen and 4 given $50 \mathrm{~g}$ of fresh pollen collected during the summer of 1980 . These two treatments were incluted as controls and fed to colonies containing $400 \mathrm{~g}$ of bees since this was the population used in previous studies.

The basic diet contained lactalbumin-yeast as the protein source (one part lactalbumin and two parts yeast) formulated with enough sucrose and water to give a $23 \%$ protein level. Each diet was offered to bees by placing it in a plastic petri dish lid $(15 \times 100 \mathrm{~mm})$ and inverting the lid over the top bars of each hive.

Diet and sugar syrup ( $50 \% \mathrm{w} / \mathrm{v}$ ) were replaced weekly during the 12 -week test and the unused portion of the diet was weighed. Fresh water was provided ad lib. by filling a tray containing small gravel in the bottom of each cage. After the first capped brood was observed, the number of sealed cells was estimated biweekly using a wire grid with $6.45 \mathrm{~cm}^{2}$ divisions.

The data were analyzed by two way analysis of variance and differences were grouped according to Duncan's Multiple Range Test.

\section{RESULTS AND DISCUSSION}

The amount of sealed brood reared and diet consumption by caged bees averaged over the 12-week test period are shown in Table 1. Bees in treatment 1 contained only spotty brood after 2 weeks, while for the same time period both treatments 2 and 3 contained 66 and $50 \mathrm{~cm}^{2}$ of sealed brood, respectively. Bees in treatment 1 reared the smallest amount of brood of the three treatments populated with $200 \mathrm{~g}$ of bees. There was no statistical difference in the rate of brood rearing by treatments 2 and 3 . 
TABL. 1. - Brood rearing $\left(\mathrm{cm}^{2}\right)$ and diet consumption $(\mathrm{g})$ by colonies established with 200,400 , or $600 \mathrm{~g}$ of bees.

\begin{tabular}{c|c|c|c|c}
\hline Treatment & Bees $(\mathrm{g})$ & $\begin{array}{c}\text { Diet } \\
\text { Offered }(\mathrm{g} / \mathrm{wk})\end{array}$ & $\begin{array}{c}\text { Diet } \\
\text { Consumed }(\mathrm{g} / \mathrm{wk})\end{array}$ & $\begin{array}{c}\text { Sealed Brood } \\
\left(\mathrm{cm}^{2} / \mathrm{wk}\right)\end{array}$ \\
\hline 1 & 200 & 25 & $23 d(3)$ & $46.44 \mathrm{ef}(3)$ \\
2 & 200 & 50 & $40.8 b$ & $89.65 \mathrm{bc}$ \\
3 & 200 & 100 & $43.6 b$ & $78.84 \mathrm{~cd}$ \\
4 & 400 & 25 & $23 d$ & $57.40 \mathrm{def}$ \\
5 & 400 & 50 & $41.7 b$ & $98.68 \mathrm{bc}$ \\
6 & 400 & 100 & $58.7 a$ & $125.13 a$ \\
7 & 600 & 25 & $22.4 d$ & $37.41 \mathrm{f}$ \\
8 & 600 & 50 & $45 d$ & $99.97 b$ \\
9 & 600 & 100 & $58.8 a$ & $134.16 a$ \\
$10(1)$ & 400 & 50 & $32.2 c$ & $61.92 \mathrm{de}$ \\
$11(2)$ & 400 & 50 & $43.3 b$ & $138.67 a$ \\
\hline
\end{tabular}

(1) One-year-old pollen (1979).

(2) Pollen collected fresh during the summer of 1980.

(3) Means in the same row followed by the same letter do not differ significantly at the $5 \%$ level of probability as calculated by Duncan's multiple range test.

Colonies populated with $400 \mathrm{~g}$ of bees (treatments 4,5 , and 6) reared the greatest amount of brood when offered $100 \mathrm{~g}$ of diet and the least when offered $25 \mathrm{~g}$ of diet per week.

Treatment 7 ( $600 \mathrm{~g}$ of bees offered $25 \mathrm{~g}$ of diet) reared the smallest amount of brood of any colony in this study. The amount of available diet was apparently not adequate for the large population and only when $100 \mathrm{~g}$ of diet was offered each week (treatment 9) were these bees able to rear brood in excess of $150 \mathrm{~cm}^{2}$ per week. Treatment $9\left(600 \mathrm{~g}\right.$ of bees offered $100 \mathrm{~g}$ diet) contained $130 \mathrm{~cm}^{2}$ of sealed brood after 2 weeks which was the greatest of any treatment including the 1979 and 1980 pollen controls ( 70.9 and $54.8 \mathrm{~cm}^{2}$, respectively).

Bees offered the 1-year-old pollen (treatment 10) reared less brood and consumed smaller amounts than bees offered fresh pollen (treatment 11). Even though the pollen was air-dried and stored in a freezer, deficiencies in vitamins or amino acids must have reduced its biological activity. The brood pattern was spotty throughout the experiment, and most brood rearing had ceased by the 12th week. Only two of the four units contained sealed brood after 12 weeks although the units without brood were queen-right.

When $25 \mathrm{~g}$ of diet was offered each week, bees in all treatments containing either 200,400 , or $600 \mathrm{~g}$ of bees consumed most of the diet. Units containing 200 and $400 \mathrm{~g}$ of bees rarely consumed $50 \mathrm{~g}$ per week, but units established with $600 \mathrm{~g}$ of bees consumed $50 \mathrm{~g}$ of diet 5 times during the study. At no time did bees completely consume $100 \mathrm{~g}$ of diet. 
Bees offered the 1980 pollen reared twice as many bees to the sealed stage as bees fed the 1979 pollen. However, the mean weekly consumption for 1980 pollen $(43.3 \mathrm{~g})$ was not proportionally greater than the amount consumed by bees offered the 1979 pollen $(32.2 \mathrm{~g})$.

The linear regression for brood rearing by various populations of bees are shown in Figure 1. The linear equation and $r^{2}$ value (coefficient of determination) for each treatment is included on this graph. This data indicate that the amount of available diet influenced the rate of brood rearing more than the populations, especially when $100 \mathrm{~g}$ of diet were made available weekly. Yields of brood increased with available diet in all three population levels. The greatest differences between the amount of sealed brood reared by all three populations occurred when $25 \mathrm{~g}$ of diet was offered each week. Units with $600 \mathrm{~g}$ of bees reared the smallest amount of brood followed by the $200 \mathrm{~g}$ population, and the most brood was reared by units populated with $400 \mathrm{~g}$ of

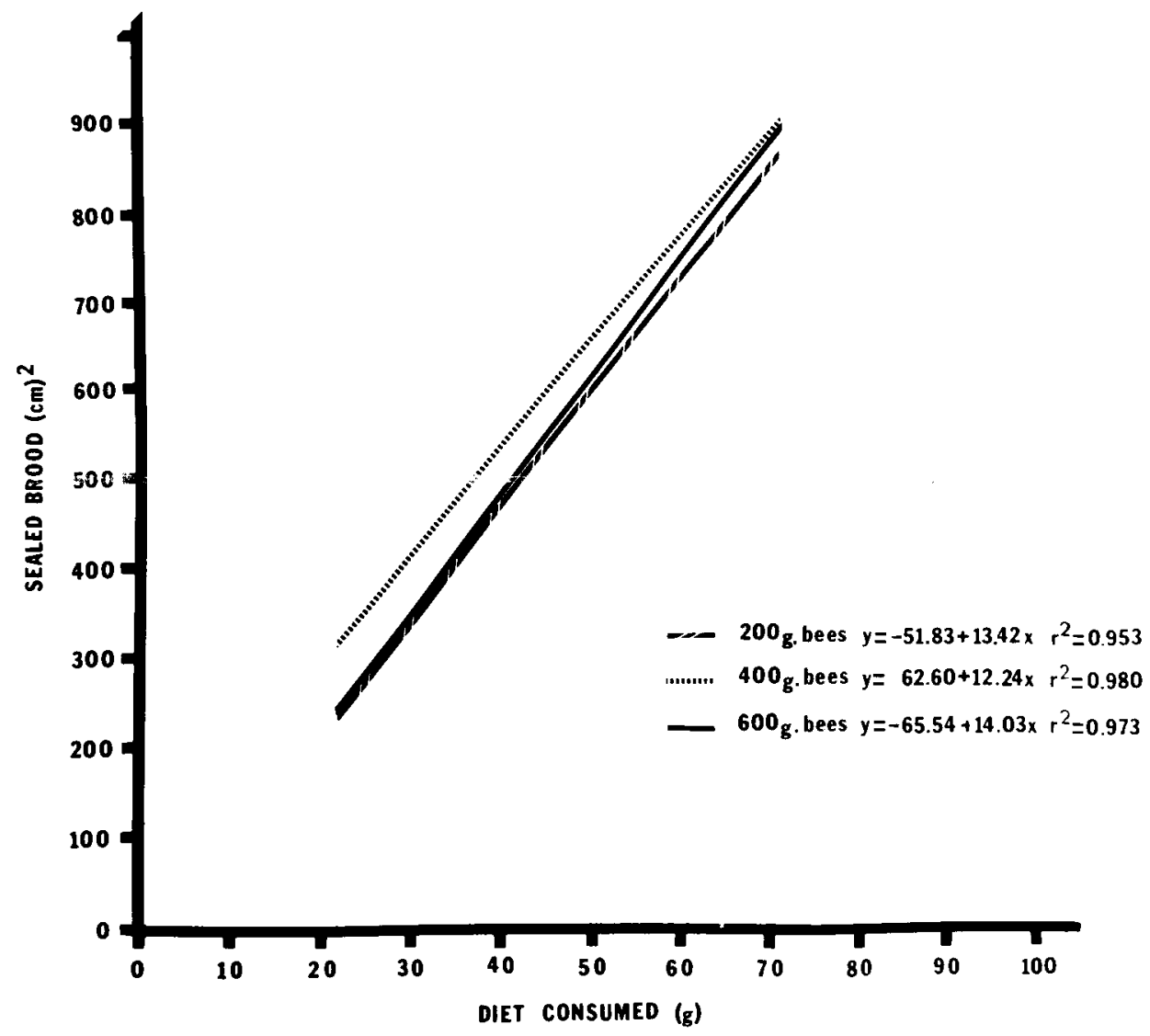

FIG. 1. - Brood rearing $\left(\mathrm{cm}^{2}\right)$ and diet consumption (g) by 200, 400, or $600 \mathrm{~g}$ of honey bees offered lactalbumin-yeast pollen substitutes. 
bees. Units containing $200 \mathrm{~g}$ of bees probably do not contain adequate adults to care for the immature bees. When a colony has more larvae than it can feed, those in a small area are fed, but the rest are neglected and die (GONTARSKI, 1953). In the case of units populated with $600 \mathrm{~g}$ of bees, the $25 \mathrm{~g}$ of diet must have created protein deficiencies. FREE (1966) reported that when protein levels are not adequate, workers adjust the amount of brood to suit current circumstances by eating or neglecting some of the eggs and young larvae.

The analysis of variance for sealed brood and diet consumption are included in Table 2. There were significant differences in interactions for population (pop), diet, pop $x$ diet and diet $x$ date when brood was the dependent variable. When diet was the dependent variable, all interactions were highly significant with the exception of rep $\times$ date, which was not significant.

TABL. 2. - Analysis of variance for sealed brood and diet consumption by colonies of bees containing 3 different population densities.

\begin{tabular}{|c|c|c|c|c|}
\hline \multirow{3}{*}{ Source } & \multicolumn{4}{|c|}{ Dependent variable } \\
\hline & \multicolumn{2}{|c|}{ Brood } & \multicolumn{2}{|c|}{ Diet } \\
\hline & $\mathrm{df}$ & $F$ value & $\mathrm{df}$ & F value \\
\hline Date & 5 & $38.62 * *$ & 12 & $31.84^{* *}$ \\
\hline Rep $\times$ date $(1)$ & 18 & $\begin{array}{r}0.78 \\
0.78\end{array}$ & 39 & 0.84 \\
\hline Pop & 2 & $8.57^{* *}$ & 2 & $13.62 * *$ \\
\hline Diet & 2 & $67.39 * *$ & 2 & $284.41 * *$ \\
\hline Pop $\times$ diet & 4 & $5.85^{* *}$ & 4 & $9.09^{* *}$ \\
\hline Pop $\times$ date & 10 & 0.69 & 24 & $5.16^{* *}$ \\
\hline Diet $x$ date & 10 & $3.35 *$ & 24 & $6.80^{* *}$ \\
\hline Pop $x$ diet $x$ date & 20 & 1.22 & 48 & $3.62 * *$ \\
\hline
\end{tabular}

(1) Used to test date.

* Significant at the 0.05 probability levels.

** Significant at the 0.01 probability levels.

The correlation coefficients $(r)$ for brood and diet are shown in Table 3 . The correlation for 1980 pollen $(r=0.15220)$ was unexpectedly lower than the value for 1979 pollen $(r=0.77638)$. This can possibly be explained by the variation in the protein level of pollen collected during 1980. This pollen was collected from free flying colonies and fed to our experimental bees during the same week. The protein levels varied during this period (15.44\%-27.56\% protein); whereas, the pollen collected in 1979 was used throughout this study and the protein level did not change ( $31.4 \%$ protein). In the case of the 1980 pollen, there was little or no correlation between the rate of brood rearing and the amount of diet consumed. Consumption of the 1980 pollen diet was consistent throughout the experiment; whereas, the 1979 
TABL. 3. - Correlation coefficients (r) for brood $\times$ amount of available diet by 3 population densities of honey bees.

\begin{tabular}{c|c|c|c}
\hline \hline Treatment & Population $(\mathrm{g})$ & Available diet $(\mathrm{g})$ & $\begin{array}{c}\text { Correlation coefficient } \\
(r) \text { of brood } \times \text { diet }\end{array}$ \\
\hline 1 & 200 & 25 & -0.07117 \\
2 & 200 & 50 & 0.50800 \\
3 & 200 & 100 & 0.71733 \\
4 & 400 & 25 & 0.17415 \\
5 & 400 & 50 & 0.40080 \\
6 & 400 & 100 & 0.66997 \\
7 & 600 & 25 & 0.35014 \\
8 & 600 & 50 & 0.03007 \\
9 & 600 & 100 & -0.11653 \\
10 & $400(1)$ & 50 & 0.77638 \\
11 & $400(2)$ & 50 & 0.15220 \\
\hline
\end{tabular}

(1) One year old pollen (1979).

(2) Pollen collected fresh during the summer of 1980.

pollen was consumed early in the study and consumption decreased with time. Brood rearing in the units offered the 1979 pollen followed the same general curve, peaking early then falling off with time. In the case of the 1980 pollen fed bees, the rate of brood rearing continued to increase reaching a plateau during weeks 6,8 , and 10. After 12 weeks these units contained as much brood as they did early in the experiment.

Our data using caged bees agrees with those of FREE (1968) using free flying colonies. Free noted that colonies with brood tended to have similar amounts irrespective of their population and the ratio of brood/bees was greater in the smaller colonies. FreE also noted that more food was consumed per bee in smaller than in large colonies. Our studies seem to substantiate FREE's observations since our smaller units consumed proportionally more diet than larger units offered the same amount of diet. FARRAR (1932) and MOELLER (1961) noted that smaller colonies rear proportionally more brood per bee in spring and continue brood rearing later in the Autumn. Doull (1973) suggested that the rate of brood rearing varied in direct relationship to the amount of pollen available in the hive. However, the amount of brood rearing in the present study varied during the test period even though the amount of available diet remained constant.

The limits in our experimental units would seem to be the number of cells available to the queen for egg laying since we observed that unlimited amounts of diet did not result in unlimited amounts of brood. At no time, however, did space availability become limiting since the feeding of sugar syrup was closely monitored to prevent the queen from becoming " honey bound $n$. 
This study indicates that the optimal colony size required for maximum brood rearing in a $2 \times 2 \times 2 \mathrm{~m}$ cage would involve a population of 400 to $600 \mathrm{~g}$ of bees offered $100 \mathrm{~g}$ of diet (unlimited diet) each week.

Received for publication in A ugust 1981.

\title{
ZUSAMMENFASSUNG
}

\author{
EFFEKT DER POPULATIONSDICHTE UND DES BEREITGESTELLTEN FUTTERS \\ AUF DIE RATE DER BRUTAUFZUCHT DURCH HONIGBIENEN, \\ DENEN EIN POLLENERSATZ ANGEBOTEN WURDE
}

Es wurde die Menge der Brutaufzucht und des Futterverbrauchs von Bienenvölkern gemessen, die mit 200,400 und $600 \mathrm{~g}$ frisch geschlüpften Bienen gebildet worden waren; jeder Population wurden pro Woche je 25, 50 oder $100 \mathrm{~g}$ eines Pollenersatzes aus Lactalbumin und Hefe geboten. Zusätzlichen Kontrollvölkern wurde entweder ein Jahr alter Pollen oder frisch gesammelter Pollen aus frei fliegenden Völkern geboten.

Die Bienen in Versuchsansatz 1 ( $200 \mathrm{~g}$ Bienen mit einem Futterangebot von $25 \mathrm{~g})$ zogen von allen drei Versuchsansätzen mit der gleichen Bienenmenge $(200 \mathrm{~g})$ die kleinste Brutmenge auf. Völker mit $400 \mathrm{~g}$ Bienen (Ansätze 4, 5, und 6) zogen am meisten Brut, wenn sie pro Woche $100 \mathrm{~g}$ Futter erhielten, und am wenigsten mit $25 \mathrm{~g}$ Futter.

Bei Versuchsansatz 7 (600 g Bienen mit einem Futterangebot von $25 \mathrm{~g}$ ) erzeugten die Bienen die geringste Brutmenge von allen in diesem Versuch eingesetzten Völkern. Die Menge des gebotenen Futters war offenbar für diese grosse Population nicht ausreichend.

Bienen, denen der ein Jahr alte Pollen geboten wurde, erzeugten weniger Brut und verbrauchten weniger als Bienen, die frischen Pollen erhielten. Obwohl der Pollen luftgetrocknet und in einem Kühlschrank aufbewahrt war, musste das Fehlen von Vitaminen oder Aminosäuren seine biologische Aktivität herabgesetzt haben. Die Brutflächen waren während des ganzen Experiments lückenhaft und zur 12. Woche hatte die Bruttätigkeit zum Grossteil ganz aufgehört.

Die lineare Gleichung und der $r^{2}-$ Wert (Bestimmtheitskoeffizient) zeigten für jeden Versuchsansatz, dass die Menge des vorhandenen Futters den Brutumfang stärker beeinflusste als die Populationstärke, vor allem dann, wenn wöchentlich $100 \mathrm{~g}$ Futter angeboten wurden. Bei allen drei Volksstärken nahm die Brut mit der Menge des gebotenen Futters zu. Die meiste Brut bis zur Verdeckelung wurde von Einheiten aufgezogen, die mit $400 \mathrm{~g}$ Bienen besetzt waren und die wöchentlich $100 \mathrm{~g}$ der Futtermischung erhielten.

\author{
RÉSUMÉ \\ INFLUENCE DE LA DENSITÉ DE POPULATION ET DE LA DISPONIBILITÉ \\ EN NOURRITURE SUR LE TAUX D'ÉLEVAGE DU COUVAIN \\ PAR DES ABEILLES NOURRIES AVEC UN SUCCÉDANE DE POLLEN
}

On a mesuré la quantité de couvain élevé et la consommation alimentaire par des tolonies d'abeilles composées de 200,400 ou $600 \mathrm{~g}$ d'abeilles récemment écloses, lorsqu'on leur offrait 25,50 ou $100 \mathrm{~g}$ par semaine d'un mélange de levure et de lactalbumine comme succédané de pollen. A d'autres colonies, servant de témoins, on a donné soit du pollen vieux d'un an, soit du pollen frais récolté par des colonies. Parmi les 3 lots peuplés de $200 \mathrm{~g}$ d'abeilles, celui qui a subi le traitement 1 ( $25 \mathrm{~g}$ de nourriture pour $200 \mathrm{~g}$ d'abeilles) a élevé le moins de couvain. Les colonies peuplées avec $400 \mathrm{~g}$ d'abeilles (traitements 4,5 et 6 ) 
ont élevé le plus de couvain lorsqu'on leur a donné $100 \mathrm{~g}$ de nourriture et le moins lorsqu'on leur en a donné que $25 \mathrm{~g}$ par semaine.

Le lot ayant subi le traitement 7 ( $25 \mathrm{~g}$ de nourriture pour $600 \mathrm{~g}$ d'abeilles) a élevé la plus petite quantité de couvain de tous les lots. La quantité de nourriture disponible ne convenait visiblement pas pour une grande population.

Les abeilles qui ont reçu du pollen vieux d'un an ont élevé moins de couvain et consommé de plus petites quantités que celles qui avaient du pollen frais. Bien que le pollen ait été séché à l'air et conservé en congélateur, des déficiences en vitamines ou en acides aminés ont dû réduire son activité biologique. Le nid à couvain a été clairsemé tout au long de l'expérience et la majeure partie de l'élevage avait cessé à la $12^{\mathrm{e}}$ semaine.

L'équation linéaire et la valeur $\mathrm{du} r^{2}$ (coefficient de détermination) pour chaque traitement ont montré que la quantité de nourriture disponible influençait le taux d'élevage du couvain plus que la population, surtout lorsque $100 \mathrm{~g}$ de nourriture était disponible par semaine. Les productions de couvain ont augmenté avec la quantité de nourriture disponible pour les trois niveaux de population. Le lot qui a élevé le plus de couvain jusqu'au stade operculé est celui constitué de $400 \mathrm{~g}$ d'abeilles et de $100 \mathrm{~g}$ de nourriture.

\section{LITERATURE}

Doull K. M., 1973. - Relationships between pollen, brood rearing and consumption of pollen supplements by honeybees. Apidologie, 4 (4), 285-293.

Farrar C. L., 1937. - The influence of colony populations on honey production. Jour. Agr. Res., 54 (12), 945-954.

FrEE J. B., 1966. - Seasonal regulations in the honeybee colony. In Regulation and Control in Living Systems, ed. by H. Kalmus. p. 351-379.

FreE J. B. and RACEY P. A., 1968. - The effect of the size of honeybee colonies on food consumption, brood rearing and the longevity of bees during winter. Ent. Exp. and Appl., 11, 241-249.

GONTARSKI H., 1953. - Contributions to the brood biology of the honeybee. Z. Bienenforsch, 2 (1), 7-10.

MOELLER F. E., 1961. - The relationship between colony populations and honey production as affected by honey bee stock lines. U.S.D.A. Production Research Report No. 55. 20 p. 